\title{
The Urbanization of drone warfare: policing surplus populations in the dronepolis
}

\author{
Ian G. R. Shaw \\ School of Geographical and Earth Sciences, The University of Glasgow, G12 8QQ, Glasgow, UK \\ Correspondence to: Ian G. R. Shaw (ian.shaw.2@glasgow.ac.uk)
}

Received: 9 September 2015 - Revised: 22 December 2015 - Accepted: 26 January 2016 - Published: 15 February 2016

\begin{abstract}
This paper explores the urbanization of drone warfare and the securitization of the "surplus population". Defined as a bloc of humanity rendered as structurally unnecessary to a capital-intensive economy, the surplus population is an emerging target for the post-welfare security state. If we now live in an age of a permanent conflict with uncertain geographies, then it is at least partly fueled by this endemic crisis at the heart of the capitalist world system. Of key significance is the contradictory nature of the surplus population. The "security threat" generated by replacing masses of workers with nonhumans is increasingly managed by policing humans with robots, drones, and other apparatuses. In other words, the surplus population is both the outcome and target of contemporary capitalist technics. The emerging "dronification of state violence" across a post-9/11 battlespace has seen police drones deployed to the urban spaces of cities in Europe and North America. The drone, with its ability to swarm in the streets of densely packed urban environments, crystallizes a more intimate and invasive form of state power. The project of an atmospheric, dronified form of policing not only embodies the technologization of state security but also entrenches the logic of a permanent, urbanized manhunt. The paper concludes by discussing the rise of the dronepolis: the city of the drone.
\end{abstract}

\section{Introduction}

This paper is driven by the intersection - or collision - of a growing number of surplus populations across the world and the contemporary "dronification of state violence" (Shaw and Akhter, 2014). While drones are now routinely used as military technologies in the so-called peripheral spaces of the planet - Pakistan's tribal areas, Yemen, Somalia, Afghanistan, and the occupied Palestinian territories - the urbanized, capital-intensive metropolises of the Global North are increasingly becoming targets of drone surveillance. Police forces are turning towards these robots for securing the economic insecurities of the contemporary urban landscape. Accordingly, the goal of this paper is to consider how and why drones will be used to police and pacify what Marx (1990) first called "surplus populations" in the robotizing economies of the Global North. Doing so, I suggest, highlights what could be called the urbanization of drone warfare: the rise of robotic manhunting in the cities of North America and Europe. Indeed, the drone is set to become a central technology for policing the fissiparous and paranoid borders of the emerging dronepolis: the city of the drone.

"If the point of the war against terrorism", argues Davis (2004:15), "is to pursue the enemy into his sociological and cultural labyrinth, then the poor peripheries of developing cities will be the permanent battlefields of the twentyfirst century". Yet this geography of militarized peripheries fails to account for how the urban landscapes of the Global North, or the metropole, are always-already battlespaces, striated by lives that are valued and lives that are disposable. Discussing this colonial short circuit, Wall (2013:34) writes, "The case of police drones speaks directly to the importation of actual military and colonial architectures into the routine spaces of the 'homeland', disclosing insidious entwinements of war and police, metropole and colony, accumulation and securitization." Accordingly, we must account for the hyperproximate geographies of what McIntyre and Nast (2011) call the biopolis and the necropolis: the city of the living and the city of the socially dead. These segregated spaces, rather than conforming to colonial divisions, or even national dis- 
tinctions, now generate the conditions for a type of "everywhere war" (Gregory, 2011) within the cities of the Global North. My purpose is not to privilege these homeland geographies but to show how the dronification of policing will be inseparable from the growing numbers of surplus populations in Europe and North America. This paper thus advances established debates about the amorphous post-9/11 battlespace (Graham, 2010; Gregory, 2011; Shaw, 2013). But it does so from a perspective that understands the surplus population as both the outcome and target of contemporary capitalist technics.

"A spectre is haunting Europe", declared Karl Marx and Friedrich Engels in their famous nineteenth-century manifesto, "- the spectre of communism." But other specters now haunt Europe: the ghosts of the exiled and the disposable. In the streets across Europe, in the shadows of skyscrapers and shopping malls, one stumbles upon great blocs of humanity unable to find work. For example, at the end of 2015, the 28 member nations of the EU had an average unemployment rate of $9.1 \%$, a figure that masks big regional differences. In Spain and Greece, the unemployment rate in 2015 stood at 21.4 and $24.6 \%$, respectively (Eurostat, 2015). These people have been rendered superfluous to the socioeconomic order of things. As Davis (2004:11) puts it, "This outcast proletariat - perhaps 1.5 billion today, 2.5 billion by 2030 " - represents "a mass of humanity structurally and biologically redundant to global accumulation and the corporate matrix." Young persons are overrepresented, with approximately $21 \%$ of all under- 25 s without work in Europe. "Both the evidence of recent trends and the evaluation of future prospects", writes Harvey (2014a:108), "point in one direction: massive surpluses of potentially restive redundant populations."

A proliferation of research has gone into describing the "informal proletariat", the "precariat", the "new poor", or "neo-proletariat". Such terms "connect more or less with Marx's project to identify the process that relegates a large portion of the world's population to irregular, insecure, temporary and precarious forms of employment" (Neilson and Stubbs, 2011:436). Research on surplus populations in human geography has focused on political issues surrounding who lives, who dies, and who decides (Cowen and Siciliano, 2011; Tyner 2013). Other work has looked into the particular spatial regimes of surplus populations (Gidwani and Reddy, 2011; McIntyre and Nast, 2011). While it may embody a universalizing tendency in capitalism, the surplus population produces - and is policed by - a distinct set of geographies that are inseparable from the contradictions of the urban age.

The millions of people who are continually thrown outside the formal economy - the "restive redundant populations" Harvey (2014a) discusses - present a threat to continued capital accumulation and social cohesion. The surplus population is thus becoming the site of increased (geo)political importance in the Global North as national security threats are tied to an outcast population (Tyner, 2013:708). Indeed, these blocs of humanity frequently make their voices heard: in the riots of London in 2011, the unrest in les banlieues in Paris, or the ongoing protests across Greece. Unemployment and inequality, even amongst conservative commentators, are now viewed as threats to social stability. "Countries facing high or rapidly rising youth unemployment", warns the International Labour Organization (2015:12), "are especially vulnerable to social unrest." Accordingly, surplus lives are becoming the object of intrusive forms of surveillance, securitization, and militarization. "As the number of superfluous persons increases", observes Hudson (2011:1671), "the need to contain them spatially increases, along with stricter, more aggressive measures of social control." Indeed, the material, psychological, and emotional shocks created by a robotizing form of capitalism are generating immense insecurities that are embodied in the urban ecologies of surplus populations.

For decades, these precarious - and at times dangerous milieus have been managed by various policing technologies, from CCTV to patrol cars. In this sense, what John Maynard Keynes first labelled as "technological unemployment" is tied to the "technologization of security" (Ceyhan, 2008). The helicopter, in particular, has enforced a vertical form of security. As Adey (2010:52) argues, "megacity security marches to the rotator-beat of the police helicopter, fuelled by a military technophilia and in a context of the biopolitical desertion of the city's most vulnerable." Policing, of course, has always been a spatial power. As Herbert (1997:13) observes, "the processes of internal pacification so central to the authority of the modern state readily depend on the capacity of the police to mark and enact meaningful boundaries, to restrict people's capacity to act by regulating their movements in space." Yet the drone age is colliding with the urban age to produce a new, more intimate geography of atmospheric security. How, then, might we understand the emerging geographies of "unmanned" policing (Wall, 2013)?

The first decade of the war on terror saw US military and CIA drones concentrated to the mountainous and remote geographies of Pakistan (Shaw and Akhter, 2012), and later Yemen and Somalia. In recent years, however, drones in and beyond the USA have been trialed by police forces as part of a revanchist military urbanism (Graham, 2010). Gregory (2011), for example, discusses the existence of the everywhere war, and writes that "war has become the pervasive matrix within which social life is constituted." Yet perhaps we need to reverse this formulation, such that it is social life that is - and always has been - the pervasive matrix in which war is constituted. The political and geopolitical crises endemic to the surplus population collapse both "war power" and "police power" in contrapuntal geographies, such that Neocleous' (2014:162) notion of the everywhere police is a productive analytic for diagnosing our contemporary condition. Under this understanding, social problems are alwaysalready militarized, and domestic space is always-already a battlespace. For example, the long history of aerial policing 
and pacification of "restive" populations (Satia, 2014) is inseparable from colonial and capital expansion.

Yet the contemporary management of surplus populations may yet prove a decisive break from the past. This paper will argue that drones, and micro-drones in particular, are generative of newer, more pervasive spaces of social control. The dronification of state violence not only embodies the ongoing robotization of state security but also materializes the logic of a permanent urban manhunt. Moreover, as the sheer volume of surplus humanity increases, the state is turning towards automated and algorithmic systems to manage them (Amoore, 2009). This, in turn, removes human administrators from the loop. In other words, a quantitative rise in surplus populations is facilitating a qualitative change in the biopolitical systems deployed by the state to manage them (Shaw and Akhter, 2014). The passage from a (Keynesian) welfare state to a (neoliberal) security state (Hallsworth and Lea, 2011) has created more capital-intensive forms of warfare and policing. This includes an armada of security apparatuses, from biometrics and CCTV to "pre-emptive" or "predictive" policing in forces such as the Los Angeles Police Department or the Metropolitan Police in the UK. And we can now can add the drone to this form of everywhere policing, which materializes a new set of technics for an older social war between capital accumulation and labor.

Crucially, police drones are not inert objects that simply "add" to preexisting forms of authority, but mediators that actively transform the very logics of state power (Meehan et al., 2013; Shaw and Meehan, 2013). Unlike the helicopters prowling above the Los Angeles skyline, smaller drones that can pervade and saturate the urban volume complicate the very idea of remote surveillance. The drone, and micro-drone in particular, with its ability to swarm in the streets of densely packed urban environments, holds the potential for more intimate and invasive forms of state power. This not only intensifies the coverage and mobility of existing state technics but is fundamentally transforming them. What follows is a provocative analysis into surplus populations, their geography, and the future of urban policing. My purpose is to gather together various economic and social trajectories that point towards the rise of the hyper-secured dronepolis.

\section{Surplus humanity and robotic capitalism}

In this section, I want to explore the animating contradiction of the paper: the creation of surplus populations. Marx (1990:782) crystallized the idea that a bloc of unemployed - or infrequently employed - humanity was a direct consequence of capital accumulation. The term should not be confused with Thomas Malthus' ideas about overpopulation. Marx understands the surplus population not in absolute terms, but in relation to capital. As Li (2009:68) clarifies, Marx's use of "relative" signals "the continuous tendency of capital to concentrate labour's productive capac- ity into labour-displacing technologies." Although there are lots of factors that influence the changing numbers of surplus populations, the one that I want to focus on is the ratio between constant capital (i.e., the technological means of production) and variable capital (i.e., human labor power). A persistent trend in capitalism is to augment, replace, and devalue variable capital with constant capital. The mechanization of the factory in the nineteenth century partly fulfilled this function. Today it is reflected in the ongoing robotization of economic activity. In both cases, the surplus population "set free" by constant capital further devalues human labor, constituting "a mass of human material always ready for exploitation" (Marx, 1990:784).

However, a surplus population is not an effective source of demand. Capital must still realize a profit by selling goods to a growing population made redundant by technics. Capital is perennially caught in this contradictory unity between production and realization (Harvey 2014a:81). "Technological advances", argues Hudson (2011:1667), "mean that capital is increasingly unable to absorb the world's massive (and growing) surplus population." Yet for for much of the twentieth century, technological unemployment was mitigated by ongoing economic growth, particularly in the service sector. But what happens when the fast-food worker, the telemarketer, and the administrator alike are all replaced by technics - whether computers or robots? Skilled and cognitively intensive work, traditionally a form of employment difficult to capitalize, is now vulnerable. In 2015 a Bank of England study warned up to 15 million "jobs in Britain are at risk of being lost to an age of robots" (Elliot, 2015). Other research has suggested that, within decades, $47 \%$ of jobs could be lost to automation in the USA (Frey and Osborne, 2013).

The automation of sectors across capitalism is reaching levels in which income growth - already stagnant in many developed countries - is now massively outstripped by capital returns. "When the rate of return on capital exceeds the rate of growth of output and income", writes Piketty (2014:1), "as it did in the nineteenth century and seems quite likely to do again in the twenty-first century, capitalism automatically generates arbitrary and unsustainable inequalities." Capitalism in the twenty-first century, then, is constituted by increasing levels of nonhuman capital. The rate of return on physical assets and financial instruments, together with the substitution of labor with technics, considerably exceeds income growth. Piketty symbolizes this inequality as $r>g$, what he describes as the fundamental contradiction of capital.

If the Industrial Revolution exacerbated this fundamental contradiction, then what of the robotic revolution today? This is a highly debated question amongst economists. Certainly, the impulse towards a "robotized economy in which one can increase production at will simply by adding more capital" (Piketty, 2014:217) exists, even if its total realization is near impossible. Nonetheless, the technical barriers towards a heavily robotized economy are dissolving all the time. The 
elasticity of substitution between capital and labor increases with advances in artificial intelligence. As robots become smarter and cheaper, humans become more replaceable. Perhaps more importantly, "Robots do not... complain, answer back, sue, get sick, go slow, lose concentration, go on strike, demand more wages, worry about conditions, want tea breaks or simply refuse to show up" (Harvey 2014a:103). This inegalitarian impulse could, however, be stymied by political revolution. Unless, of course, "one peculiarly effective repressive apparatus exists to keep it from happening" (Piketty, 2014:263). And herein lies the rub of the matter. The surplus population could become a social force that capital - backed by state welfare mechanisms - "bargains" with to produce a "new deal". Or else it could be targeted by a "peculiarly effective repressive apparatus". It is this latter future I expand upon below.

\section{Technological unemployment and its discontents}

Technological advancements risk centralizing capital in the hands of fewer and fewer people. The uneven power relations endemic to such a robotized economy - one that is splintering away from the surplus populations it creates is thus cause for serious concern. Accordingly, we must understand Piketty's abstract mathematical law, $r>g$, as underwritten by immeasurable social discontents. Indeed, Piketty fails to account for these kinds of dynamics, according to Harvey (2014b), who argues that the relative power of labor has declined since the 1970s, and this is because capital has mobilized technologies, off-shoring, and anti-labor "supplyside" politics to crush opposition. Moreover, after two centuries of machine-based capitalism, the physical conditions for many in the Global North may have improved, yet the vast majority of work is still defined by repetitive, menial tasks - or, for lack of a better word, drudgery. As anthropologist Graeber (2013) writes, the modern proliferation of "bullshit" jobs is one outcome of the technologization of work. "Accumulation of wealth at one pole is, therefore, at the same time accumulation of misery, the torment of labour, slavery, ignorance, brutalization and moral degradation at the opposite pole" (Marx, 1990:799).

Marx used the term alienation to describe the condition of losing one's existential autonomy to the technical and social machinery of the bourgeoisie. This exteriorization of self is a hallmark of capitalism: the worker sells their labor in the production process. Moreover, this alienated relationship between subject and object suffuses everyday life. While the human has always reached beyond its fleshy boundaries, the modern capitalist technical system it encounters today subsumes individuals within a logic of computational control, standardization, and mass psychological synchronization (Stiegler, 2011). The consequences are profound. The World Health Organization (2011) estimates that by 2030 depression will be the leading global health problem. As nonhu- man capital becomes increasingly severed from social labor, then, the technical system no longer operates with humanity. The surplus population becomes alienated en masse from a robotizing economy that no longer values human labor. Unsurprisingly, this generates a deep distrust and even outright hostility among huge swaths of society. In turn, capitalism must re-arm and re-secure its own survival, further exacerbating the very contradictions it generates.

Criminalizing, policing, and profiting from this growing surplus population is big business in the Global North. The prison-industrial complex parasitically preys on the misery of a deserted humanity. As Wall (2013:40) argues, "security capitalizes on devastation and insecurity by converting them into a plethora of opportunities for state power, social order and capitalist accumulation to be bolstered and reproduced." Indeed, surplus populations of hyper-racialized men are at the center of contemporary security politics. "The prison system", write Cowen and Siciliano (2011:1517), "has become a means of warehousing a racialized reserve army of predominantly young male labour." Up until the 1980s, a broadly demand-side, or Keynesian, form of economic policy held in Western Europe and the USA. Of course, since social security was framed within the nexus of economic security, the former was still overdetermined by the latter (see Neocleous, 2006). Nonetheless, since the 1980 s, the responsibility for welfare has shifted from the commonwealth to the individual, and supply-side tax regimes have ascended. This neoliberal counter-revolution ushered into the world a new kind of state - the security state (Hallsworth and Lea, 2011) - and a new kind of society: the control society (Deleuze 1992).

The security state is no longer responsible for ending economic inequality, but for policing it. As Hallsworth and Lea (2011:142) write, the security state aims "at the management of social fragmentation and the 'advanced marginality' of a growing global surplus population rendered 'structurally irrelevant' to capital accumulation." The counterpart of the security state is the control society. The continuing technologization of security materializes a shift from Michel Foucault's notion of a disciplinary society to what Deleuze (1992) presciently labeled the control society. Rather than just discipline "deviant" populations within state enclosures - such as prisons, asylums, schools, and barracks - the control society produces a universalizing form of control driven by computational surveillance and algorithmic governance (Amoore, 2009). Here we loop back to the central contradiction of the surplus population: it is both $\mathrm{cre}$ ated and policed by capitalist technics. As more and more jobs are replaced by nonhuman capital, the expelled workers find themselves policed, occupied, and watched by an equally robotic security armada. And in between these technics swells a profound discontent. It is in this sense that a robotizing capitalism renders vast swathes of humans as materially and psychologically insecure (Harvey, 2014a:108). 


\section{The spaces of surplus populations}

The universalizing tendency toward economic inequality is spatially concentrated in a militarized urbanism. This groups together drug addicts, terrorists, criminals, young people engaged in anti-social behavior, and immigrants - indeed, any individual that threatens the economic wellbeing of the security state. "The result is a kind of social, civil war to control domestic space" (Graham, 2010:109). This slippage between different categories of people signifies how surplus populations are continually remade into enemy populations. As Feldman (2004:332) writes, "these public safety wars are not wars of utopia, but wars of dystopia that assume that 'perfected' liberal democracies are threatened by an invisible, infiltrating menace." This infiltrating menace is the surplus population, materially and ideologically rendered as an enemy population - one that crosses geopolitical boundaries and complicates the traditional logics of sovereignty and territory. This, in turn, drives the explosion of borders everywhere, as the enemy population multiplies and self-divides. As a result, the borders of the security state no longer mark the distinction between national commonwealths, but move inwards, separating zones of urban abandonment with secessionary communities.

These paranoid and revanchist spatializations are underwritten by powerful modes of racialization (Merrill, 2011). As McIntyre and Nast (2011:1466) write, "One cannot, therefore, understand surplus populations without understanding how the geographical dynamics of accumulation have become increasingly racialized." The relationship between race and superfluity remains an active process in world politics. To conceptualize this co-imbrication between lives that are valued and lives that are surplus, McIntyre and Nast introduce the concepts of biopolis and necropolis. Following Mbembe's (2003) work on "necropolitics" - which foregrounds the primacy of death, rather than life, as a mode of sovereign power - the necropolis is the space of the socially outcast and dead, "borne through displacements, enclosures, and containments, both in the context of slavery, the colony and (initially) the nation-state" (McIntyre and Nast, 2011:1470). Its opposite is the biopolis - based on Foucault's notion of biopower - in which the sovereign protects and manages its inhabitants. "Whereas capitalists attended, however inadequately, to the problem of biological and social reproduction in the biopolis, no such concern extended to the necropolis. So long as surplus laboring populations were sufficiently large, little regard was given to the symbolic or practical course of local reproduction" (McIntyre and Nast, 2011:1471).

In the necropolis then, capital extracts surplus value. But unlike in the biopolis, it fails to reinvest in social reproduction. This spatial division is producing what Gidwani and Reddy (2011:1640) call a "techno-ecological urbanization", that is, "two sets of urban ecologies and populations - one, the ecology set of an urban bourgeoisie actively tied into global circuits of capital, whose lives are considered worthy of caring by the state; the other, the ecology set of an urban underclass living off the commodity detritus of these global circuits, whose lives are of indifference to the state". Both spaces - the necropolis and the biopolis - are thus connected in twisted geographies of economic and emotional transaction in which capital is traded for misery, and life is traded for death. Yet the necropolis and biopolis do not straightforwardly express cities positioned across national borders. As Li (2009:66) writes, "African-Americans on the south side of Chicago are 'let die' at around 60 years, while the mostly white, middle-class residents on the city's northwest side can expect to live until the age of 77.2." The necropolis, then, can be seen as a matrix of exceptional spaces within the nation state (Agamben, 2005) - spaces of abandonment that are nonetheless included in capital accumulation and state power.

The distance between the necropolis and biopolis continues to be compressed and capsularized. The idea of what de Cauter (2004) calls a capsular civilization expresses this spatial logic of a hyper-fragmented yet hyper-proximate landscape of necropolitical and biopolitical spaces. In the comfort capsules of wealth, users can access biopolitical forms of government intervention - but in the necropolitical spaces of surplus and waste, the overriding logic is to "let die". As Graham (2010:100) underscores, "Urban geographies become increasingly polarized, and cities experience palpable militarization as secessionary elites strive to sequester themselves within fortified capsules." The necropolis and biopolis thus coexist in intimate, proximate, and contrapuntal morphologies. Sloterdijk's (2011:55) spatial metaphor of "foam" describes the hyper-fragmented spaces of solitary co-isolation and co-confinement in the modern age, particularly in the city. Deploying this metaphor, we can imagine the necropolis and biopolis as foams of death and life passing next to each other in intimate and shifting bubbles, yet without any mutual overlap. Or as Klauser (2010:331) writes, the capsularized and foamy city is "an ensemble of spatially anchored, more or less hermetically enclosed, socially exclusive, and atmospherically active spheres of togetherness that are, essentially, composed by co-isolated, individuated subjects." So while the logic of securing surplus populations is an everywhere policing, what is policed is not human welfare and togetherness. Instead, it is a transcendental logic of worldly co-isolation, in which outcast bodies are monitored - and suspended - within the desperate foams of the necropolis. Of course, these borders are continually transgressed, through uprisings, riots, and more mundane disruptions of the worldly order. And it is this porosity that breeds further paranoia and its obverse: manhunting. 


\section{Manhunting}

A technologically infused manhunt is the means by which the security state polices the fissiparous borders that snake between the biopolis and necropolis. While vast swathes of humanity are "let die" in a passive form of state abandonment, those who transgress their worldly emplacing can be actively hunted down. As Chamayou (2012:89) argues, "the police is a hunting institution, the state's arm for pursuit, entrusted by it with tracking, arresting, and imprisoning." Manhunting, of course, has a much longer history than its current incarnation. Capital was born in the midst of empire and colonial manhunting. Marx (1990:915) famously argued that "the beginning of conquest and plunder of India, and the conversion of Africa into a preserve for the commercial hunting of blackskins, are all things which characterize the dawn of the era of capitalist production." Capital and manhunting thus share contrapuntal geographies: those individuals who resisted capital in the past have been hunted down. It it in this sense that the manhunt is the modus operandi of a longer history of pacification, which is to say the production and policing of bourgeois social order (Neocleous, 2013:8).

Yet the technics of manhunting are spatially and temporally contingent and ever shifting. "Technicity, as a system", observes Stiegler (2011:51), "constitutes the artificial and social system of predation and defense from the beginning of humanity." So while pacification is a project that is centuries old, the technicity of the manhunt is constantly shifting with the evolution of the worldwide military-industrial complex. And this modern manhunt is inseparable from the logic of targeting. As Cowen and Siciliano (2011:1526) write, "targeting contrasts with the implicit, typically national geography of welfarism and transforms the said goal of government from collective welfare and development to managing spatially bounded problems. Both the military and police now mobilize targeting practices 'at home' to govern overlapping populations of surplus subjects."

The war on terror materialized the most recent, and planetwide, geography of manhunting. In the wake of the terrorist attacks of 11 September 2001, the US military, CIA, NSA, and Special Forces were reengineered around a new kind of hyper-connected and transnational manhunt (Mazzetti, 2013). As President Bush announced in 2003, "We're at war in a different kind of war. It's a war that requires us to be on an international manhunt" (CNN, 2003). This leads Chamayou (2015:32) to conclude that "A single decade has seen the establishment of an unconventional form of state violence that combines the disparate characteristics of warfare and policing without really corresponding to either, finding conceptual and practical utility in the notion of a militarized manhunt." This unconventional form of globalized state violence has pivoted around the military drone, forming what I have elsewhere called a Predator Empire (Shaw, 2013). However, while there has been important research on military drones in political geography and critical security studies (Gregory, 2011; Holmqvist, 2013; Walters, 2014), the spatialities and logics of the police drone are underresearched. Yet the police drone is materializing an insidious and spatially amorphous form of pacification. The dronification of state violence crystallizes the state's project to pacify external and internal enemies as a single matrix of targets. As Wall (2013:34) argues, "police drones underline the unmanning of the police manhunt, that foundational practice of police power where the 'reserve army of labour' is quite literally hunted and captured."

Drone manhunting thus embodies two seemingly contradictory impulses: abandonment and surveillance. The surplus population is economically discarded but nonetheless watched by the state. As Handel (2011:259) argues, in contrast to the Foucaultian notion of biopolitical and inclusive surveillance that embraces its citizens in a form of sovereign governmentality, exclusionary surveillance, conversely, uses power/knowledge practices "to exclude unwanted populations". This, in other words, is a form of necropolitical surveillance. As Handel (2011:272) continues, "Exclusionary surveillance is the state of exception's operative tool. It is exclusionary surveillance that separates the people who are part of the demos from those who are excluded from it." So while a robotizing form of capitalism may continue to repel surplus populations to the outside of the economic order, they nonetheless remain on the inside of state power.

Furthermore, in tandem with the "individualization of warfare" (Blum, 2014), the security state requires that the surplus-qua-enemy populations can be disaggregated to the scale of the individual. This exerts an inexorable push towards the further technologization of security. As the sheer volume of surplus humanity increases, the state is turning towards automated systems that can manage huge volumes of individual data (Amoore, 2009; Shaw and Akhter, 2014). This constructs a technological grammar in which individuals are converted into what Deleuze (1992) called dividuals: digital codes constituted by email, phone, and financial records, which are passed between the policing assemblages of the control society. But the process does not stop there. These dividuated strings of data are spliced with spatial forms of intelligence, such as cell phone mast records, license plate readers, CCTV, and IP addresses, to produce geolocated patterns of life. "Also called nodal analysis, such geographical work is designed to make a 'shadowy foe' more 'visible and vulnerable' by revealing 'patterns of life' and thus taking him or her from being a 'foe' hiding in the shadows to a visible target" (Crampton et al., 2014:206).

The individualization of warfare is thus a double process: the human is disaggregated across a diffuse set of electronic data sets, only to be re-individuated by state technics as a moving pattern of life. "The production of this form of individuality", argues Chamayou (2014), "belongs neither to discipline nor to control, but to something else: to targeting in its most contemporary procedures, whose formal features are shared today among fields as diverse as policing, military 
reconnaissance, and marketing. It might well be, for that matter, that we are entering targeted societies." Targeting, however, should not imply a narrowing of spatial power. It relies on its necessary obverse: extension. The entire "normal" population must first be coded and modeled to geolocate the abnormal. In order to individualize, the security state must first totalize, effecting an intensive policing of the lifeworld. The two spatial optics of urban manhunting are thus population (expansion) and person (contraction), both of which are increasingly connected through the vertical orbits of the police drone. The targeted society is the robotic heir to the control society.

\section{The rise of the dronopticon?}

The atmosphere has been a crucial space of military power and colonial pacification since the birth of air power (Satia, 2014). In turn, aerial forms of civil policing were established throughout the second half of the twentieth century, as police forces in the Global North turned towards technology to fight crime. "Los Angeles, for example, developed a particular brand of policing that emphasized technological sophistication and aggressive patrolling" (Herbert, 1997:16). The LAPD currently has 19 helicopters, which were first deployed in 1956 after the establishment of its Air Support Division. Indeed, the helicopter has been a central technology for policing megacities across the world (Adey, 2010). Rotary-wing aircraft enable the police to render the urban terrain visible and impose a form of flexible, mobile control: whether through high-powered spotlights, video cameras, or loudspeakers. The helicopter materializes the state's desire to impose order upon the chaotic circulations of the city. In other cases, the helicopter enables the wealthy to bypass the surplus population entirely. Sao Paulo, for example, holds the world's most private helicopters per capita, which allow the ultra-rich to take to the skies and bypass the city's terrestrial congestion and social danger (Adey, 2010).

But how will the urbanization of drone warfare extend and rework this extant logic? On the one hand, "unmanned vertical policing extends the police dream of pacification through air power, or a scopic verticality" (Wall, 2013:42). Under this understanding, the drone intensifies already-existing regimes of aerial policing - further enclosing the targeted society from above and rendering the illegible spaces of necropolis visible. Yet drones also hold the potential to transform state technics. They materialize a more intimate form of aerial policing that challenges the notion that drones are remote technologies. Currently, the Predator and Reaper class of military drones surveil the ground from up to a flight ceiling of 25000 and 50000 feet, respectively. But a big trend in military and domestic robotics is to develop micro- or "nano"drones that can range in size from a humming bird to an insect. Crucially, by going smaller, the geographies of state surveillance become more intimate.
Most US police drones in existence today are variants of the small-scale quadcopter drones used by amateur hobbyists. Grand Forks sheriff's department in North Dakota, for example, owns four drones. This includes the quadcopter Qube, developed by AeroVironment, as well as the US military's most widely used fixed-wing drone, the hand-launched Raven (Pilkington, 2014). Moreover, advances in artificial intelligence are enabling small-scale nano-drones to cooperate together in emergent, cooperating constellations called "swarms" (Shaw and Akhter, 2012:1500). It is here that the specifics of a dronified form of policing are glimpsed. With an ability to swarm in roving robotic clouds, the (nano-)drone holds the potential to pervade, saturate, and modulate the urban volume in a way that neither the helicopter nor CCTV can adequately perform.

Adey (2014:835) has previously written that "atmospheres are becoming objects of security, whilst security itself has gone, or is going, atmospheric.” Perhaps, therefore, we are entering a new technicity of atmospheric security. Crucial to the idea of atmospheric security is that individuals can be immersed without being physically contained or touched. Jeremy Bentham's classic blueprint for a Panopticon is reflected in today's network of CCTV cameras fused to the urban architecture. This horizontal form of surveillance is complemented by the vertical power of the helicopter. But the police drone - or, rather, the police swarm - will be able to move across both axes of the city and can thus occupy street and sky simultaneously. Accordingly, the police drone disrupts the extant geometries of state power that are constrained to an $X$ and $Y$ axis. Furthermore, nano-drones would be able to move inside workplaces or perch inside of homes undetected. These drones would be able to infiltrate a range of currently inaccessible urban micro-geographies. Such future police drones thus materialize a swarm-like space of panopticism, or what could be labelled as a deterritorialized dronopoticon. There are fewer reasons to doubt that, in the future, swarms of nano-drones will pass freely through the foams of urban living, shuttling between the biopolis and necropolis, to ensure that everyone is secured in their right place.

Moreover, by securing and saturating the urban atmosphere, the police swarm not only straightforwardly mediates the technogeographies of state power but comes to recalibrate the psychological and emotional landscapes of the humans that it targets. Drone surveillance "amounts to a psychic imprisonment within a perimeter no longer defined by bars, barriers, and walls, but by endless circling of flying watchtowers above" (Chamayou, 2015:45). In places outside of the Global North, surplus populations - such as those in Palestine - are already subject to this exact form of atmopsychological security. The fractured geographies of Palestine "are not simply enclosed by Israeli-controlled land on their borders, but also above and below. Israel has refused to handover control of airspace even after its disengagement from Gaza" (Elden, 2013:48). The dronopticon, then, is more 
than an architecture of state power; it is an affective swarm capable of enclosing, hacking, and remaking the lifeworlds it infiltrates.

\section{Conclusion: the dronepolis}

Imagine a blueprint for a city to come. A city that will not only materialize the twisted contradictions of the necropolis and the biopolis but will be secured by a robotic police force hell-bent on erasing the possibility of politics. Imagine the dronepolis, the city of the drone. The dronepolis is set to become the latest in a long succession of urban forms that have pacified and policed the surplus population. It advances the logic of the machine-readable "smart city" to its natural and dystopic conclusion: a technologically infused apartheid. The lives of the valued and the surplus would be proximate topographically, but separated by advanced technics. "Clearly, any such social order could only exist on the basis of fascistic mind control and the continuous exercise of daily police surveillance and violence accompanied by periodic militarised repressions. Anyone who does not see elements of such a dystopian world already in place around us is deceiving herself or himself most cruelly" (Harvey, 2014a:264). The dronepolis materializes the logic of a capital-intensive form of exclusionary surveillance that secures segregation. Already, across many cities in the USA, an abandoned homeless population is subject to draconian antihomeless laws and hostile urban architecture. The dronepolis will be assembled by apparatuses of control that range from territorialized technologies of state power, such as CCTV, to deterritorialized swarms of nano-drones swimming between buildings. In the atmospheres of this desperate city, hypermobile police drones will surround and enter the homes of suspects, in a manhunt in which the human is transformed into an abstract pattern of life: a digital simulacrum chased across the data sets of the targeted society.

The dronepolis does not represent a decisive break from the past, then, but is a re-materialization of an alreadyexisting social war between a fortified bourgeoisie and a planetary surplus population. And it does so, increasingly, everywhere, as the logics - and profit potential - for a dronified city spread across the planet, skipping between colony and metropole. "Oligarchic capitalist class privilege and power are taking the world in a similar direction almost everywhere. Political power backed by intensifying surveillance, policing and militarised violence is being used to attack the well-being of whole populations deemed expendable and disposable" (Harvey, 2014a:292). Describing the ascendance of dronified policing, Neocleous (2014:162) writes, "This is nothing less than a permanent police presence of the reproduction of order - air power as the everywhere police - in which the exercise of violence is an ever-present possibility." And this ever-present possibility of police violence materializes a landscape of psychological terror. In its most draconian stage, the dronepolis dissolves entirely the lines between the biopolis and necropolis, such that "even those bourgeois communities and citizens usually eclipsed from the police gaze will come under the stare of unmanned policing, to that extent that air power obliterates any useful distinction between suspect and bystander, target and nontarget" (Wall, 2013:49).

Finally, many of the police drones of the dronepolis will be weaponized. While attaching lethal missiles may appear a distant reality, what about Tasers? In 2015, North Dakota became the first state to legalize less-than-lethal weaponized drones: flying robots fitted with tear gas, rubber bullets, Tasers, or beanbags (Wagner, 2015). Whether this opens the door to other police forces remains to be seen - as does the complicated and emergent geographies of legal, social, and political resistance. Additionally, non-state actors will disrupt the smooth running of the dronepolis while nonetheless feeding its power. Recently, police in Tokyo established the first "drone squad" tasked with capturing nuisance drones flown by the public, as well as patrolling important government buildings (BBC News, 2015). This atmospheric securitization followed a 2015 incident when a drone carrying a radioactive substance landed on the Japanese prime minister's office. Such a topography of ultra-secured government and corporate headquarters fitted with anti-drone shields and patrolled by police drones will be a hallmark of our looming urban landscapes. The dronepolis is the city of a robotic capitalism severing from human welfare, the city of an intimately targeted society, the city of a surplus and hyper-secured humanity.

Acknowledgements. I would like to thank the editor, Benedikt Korf, and two anonymous reviewers. Thanks also go to Francisco Klauser and Silvana Pedrozo for inviting me to the conference "Power and Space in the Drone Age" at the University of Neuchâtel, where a version of this paper was first presented. Finally, the paper has benefited from comments from Majed Akhter, Keith Hammond, Lazaros Karaliotas, Jared Powell, and Marv Waterstone. Funding for this research was provided by the Urban Studies Foundation and the ESRC (ES/K009087/1).

Edited by: B. Korf

Reviewed by: two anonymous referees

\section{References}

Adey, P.: Vertical security in the megacity: legibility, mobility and aerial politics. Theory, Culture \& Society, 27, 51-67, 2010.

Adey, P: Security atmospheres or the crystallisation of worlds, Environment and Planning D: Society and Space 32, 834-851, 2014.

Agamben, G.: State of exception, University of Chicago Press, Chicago, 2005.

Amoore, L.: Algorithmic war: Everyday geographies of the war on terror, Antipode, 41, 49-69, 2009. 
BBC News: Drone squad to be launched by Tokyo police, available at: www.bbc.co.uk/news/technology-35070818, last access 21 December 2015.

Blum, G.: The individualization of war: From war to policing in the regulation of armed conflicts, in: Law and War, edited by: Sarat, A., Doughlas, L. and Umphrey, M. M., Stanford University Press, Stanford, 48-83, 2014.

Chamayou, G.: Manhunts: A philosophical history, trans. Rendall, S., Princeton University Press, Princeton, 2012.

Chamayou, G: Patterns of life: A very short history of schematic bodies, The Funambulist, available at: http://thefunambulist.net/2014/12/04/the-funambulist-papers57-schematic-bodies-notes-on-a-patterns-genealogy-bygregoire-chamayou/ (last access: 21 August 2015), 2014.

Chamayou, G.: Drone Theory, Penguin Books, New York, 2015.

Ceyhan, A.: Technologization of security: Management of uncertainty and risk in the age of biometrics, Surveillance \& Society 5, 102-123, 2008.

CNN: Transcripts, available at: http://edition.cnn.com/ TRANSCRIPTS/0302/14/se.04.html (last access: 15 December 2015), 2003.

Cowen, D. and Siciliano, A.: Surplus masculinities and security, Antipode, 43, 1516-1541, 2011.

Crampton, J. W., Roberts, S. M., and Poorthuis, A.: The new political economy of geographical intelligence, Annals of the Association of American Geographers, 104, 196-214, 2014.

Davis, M.: The urbanization of empire: Megacities and the laws of chaos, Social Text, 22, 9-15, 2004.

de Cauter, L.: The Capsular Civilization: On the City in the Age of Fear, NAi Publisher, Rotterdam, 2004.

Deleuze, G.: Postscript on the societies of control, October, 59, 3-7, 1992.

Elden, S.: Secure the Volume: Vertical Geopolitics and the Depth of Power, Political Geography, 34, 35-51, 2013.

Elliot, L.: Robots threaten 15 m UK jobs, says Bank of England's chief economist, The Guardian, 12 November 2015.

Eurostat: Unemployment statistics, available at: http: //ec.europa.eu/eurostat/statistics-explained/index.php/ Unemployment_statistics, last access: 21 December 2015.

Feldman, A.: Securocratic wars of public safety, Interventions, 6, 330-350, 2004.

Frey, C. B. and Osborne, M. A.: The future of employment: how susceptible are jobs to computerisation?, available at: http://www.oxfordmartin.ox.ac.uk/downloads/academic/ The_Future_of_Employment.pdf (last access: 16 December 2015), 2013.

Gidwani, V. and Reddy, R. N.: The afterlives of 'waste': Notes from India for a minor history of capitalist surplus, Antipode, 43, 1625-1658, 2011.

Graeber, D.: On the phenomenon of bullshit jobs, Strike! Magazine, available at: http://strikemag.org/bullshit-jobs/ (last access: 21 August 2015), 2013.

Graham, S.: Cities Under Siege: The New Military Urbanism. Verso, London, 2010.

Gregory, D.: The everywhere war, The Geographical Journal, 177, 238-250, 2011.

Hallsworth, S. and Lea, J.: Reconstructing leviathan: emerging contours of the security state, Theoretical Criminology, 15, 141-157, 2011.
Handel, A.: Exclusionary surveillance and spatial uncertainty in the Occupied Palestinian Territories, in: Israel/Palestine: Population, Territory and Power, edited by: Zureik, E., Lyon, D., and AbuLaban, Y., Routledge, New York, 259-275, 2011.

Harvey, D.: Seventeen Contradictions and the End of Capitalism, Profile Books, London, 2014a.

Harvey, D.: Afterthoughts on Piketty's Capital, available at: http:// davidharvey.org/2014/05/afterthoughts-pikettys-capital/ (last access: 15 December 2015), 2014 b.

Herbert, S.: Policing Space: Territoriality and the Los Angeles Police Department, University of Minnesota Press, Minneapolis, 1997.

Holmqvist, C.: Undoing war: war ontologies and the materiality of drone warfare, Millennium Journal of International Studies, 41, 535-552, 2013.

Hudson, L.: A species of thought: Bare life and animal being, Antipode, 43, 1659-1678, 2011.

International Labour Organization: World Employment Social Outlook, International Labour Office, Geneva, 2015.

Klauser, F. R.: Splintering spheres of security: Peter Sloterdijk and the contemporary fortress city, Environment and Planning D: Society and Space, 28, 326-340, 2010.

Li, T. M.: To make live or let die? Rural dispossession and the protection of surplus populations, Antipode, 41, 66-93, 2009.

Marx, K.: Capital: A Critique of Political Economy, Trans. Fowkes, B., Penguin Books, London, 1990.

Mazzetti, M.: The Way of the Knife: The CIA, a Secret Army, and a War at the Ends of the Earth, The Penguin Press, New York, 2013.

Mbembe, A: Necropolitics, Public Culture, 15, 11-40, 2003.

McIntyre, M. and Nast, H. J.: Bio(necro)polis: Marx, surplus populations, and the spatial dialectics of reproduction and race, Antipode, 43, 1465-1488, 2011.

Meehan, K., Shaw, I. G. R., and Marston, S. A.: Political geographies of the object, Political Geography, 33, 1-10, 2013.

Merrill, H.: Migration and surplus populations: Race and deindustrialization in northern Italy, Antipode, 43, 1542-1572, 2011.

Neilson, D. and Stubbs, T.: Relative surplus population and uneven development in the neoliberal era: theory and empirical application, Capital \& Class, 35, 435-453, 2011.

Neocleous, M: From social to national security: On the fabrication of economic order, Security Dialogue, 37, 363-384, 2006.

Neocleous, M.: The dream of pacification: Accumulation, class war, and the hunt, Socialist Studies, 9, 7-31, 2013.

Neocleous, M.: War Power, Police Power, Edinburgh University Press, Edinburgh, 2014.

Piketty, T.: Capital in the Twenty-First Century, Trans. A. Goldhammer, Harvard University Press, 2014.

Pilkington, E: "We see ourselves as the vanguard": the police force using drones to fight crime, available at: http://www.theguardian.com/world/2014/oct/01/ drones-police-force-crime-uavs-north-dakota (last access: 17 December 2015), 2014.

Satia, P.: Drones: a history from the British Middle East, Humanity: An International Journal of Human Rights, Humanitarianism, and Development, 5, 1-31, 2014.

Shaw, I. G. R.: Predator empire: the geopolitics of US drone warfare, Geopolitics, 18, 536-559, 2013. 
Shaw, I. G. R. and Akhter, M.: The unbearable humanness of drone warfare in FATA, Pakistan, Antipode, 44, 1490-1509, 2012.

Shaw, I. G. R. and Akhter, M.: The dronification of state violence, Critical Asian Studies, 46, 211-234, 2014.

Shaw, I. G. R. and Meehan, K: Force-full: power, politics and object-oriented philosophy, Area, 45, 216-222, 2013.

Sloterdijk, P: Spheres, Volume I: Bubbles, Trans. Hoban, W., Semiotext(e), Los Angeles, 2011.

Stiegler, B.: The Decadence of Industrial Democracies: Disbelief and Discredit, Volume 1, translated by: Ross, D. and Arnold, S., Polity Press, Cambridge, 2011.

Tyner, J. A.: Population geography I: Surplus populations, Progress in Human Geography, 37, 701-711, 2013.
Wagner, L.: North Dakota legalizes armed police drones, NPR, available at: www.npr.org/sections/thetwo-way/2015/08/ 27/435301160/north-dakota-legalizes-armed-police-drones, last access: 18 December 2015.

Wall, T.: Unmanning the police manhunt: Vertical security as pacification, Socialist Studies, 9, 32-56, 2013.

Walters, W.: Drone strikes, dingpolitik and beyond: furthering the debate on materiality and security, Security Dialogue, 45, 101$118,2014$.

The World Health Organization: Global burden of mental disorders and the need for a comprehensive, coordinated response from health and social sectors ad the country level, EB130/9, 2011. 